\title{
Genetics of ovulation rate in farm animals
}

\author{
R. Kumar Pramod ${ }^{1}$, Sanjeev Kumar Sharma ${ }^{1}$, Rohit Kumar ${ }^{1}$ and Anju Rajan ${ }^{2}$
}

1. Genome Analysis Laboratory, Animal Genetics Division, Indian Veterinary Research Institute, Izatnagar, Bareilly, U.P., India; 2. Veterinary College and Research Institute, Namakkal, Tamil Nadu, India.

Corresponding author: R. Kumar Pramod, Mobile: 91-9458752091; e-mail: drpramodr@gmail.com

Received: 31-05-2013, Revised: 10-08-2013, Accepted: 11-08-2013, Published online: 20-09-2013

doi: 10.14202/vetworld.2013.833-838

How to cite this article: Kumar Pramod R, Sharma SK, Kumar R and Rajan A (2013) Genetics of ovulation rate in farm animals, Veterinary World 6(11): 833-838.

\begin{abstract}
Rate of ovulation (i.e. fecundity) is largely influenced by both genetic and environmental factors. The ovarian growth factors including members of bone morphogenetic proteins (BMPs) play a central role in determining ovulation quota and litter size. Naturally occurring mutation in sheep and knock-out and knock-down studies in murine indicated the importance of bone morphogenetic protein 15 (BMP15), growth differentiation factor 9 (GDF9) and bone morphogenetic protein receptor 1B (BMPR1B) genes in mammals. These factors have major regulatory roles during the gonadotrophin-independent and dependent stages of follicle development. Understanding of BMPs in reproduction assists in the treatment of infertility/ sterility in animals.
\end{abstract}

Keywords: bone morphogenetic proteins, follicle stimulating hormone, growth differentiation factor, knock-out, mutation.

\section{I ntroduction}

Rate of ovulation is the characteristic of a species. According to the ovulation rate, farm animals are mainly classified either as monovulators (e.g., cattle and buffalo) or multiovulators (e.g., goat and pig). The ovarian follicle development is mainly divided in to two; gonadotropin-dependent and gonadotropinindependent. Primordial to pre antral stage is gonadotropin-independent while antral follicular stage is gonadotropin-dependent. The transition from primordial to ovulatory stage is controlled by both environmental and genetic factors. Among the genetic factors, endocrines that act through so called reproductive axis (i.e. Hypothalamic - hypophyseal gonadal axis) plays an important role in follicular development and in determining the ovulation rate [1]. Follicle stimulating hormone (FSH) is considered as a primary regulator of follicle development. Subsequently, it has been shown that growth factors produced by the follicle itself can modulate FSH action through autocrine and paracrine mechanisms [2,3]. Besides coordinating the proliferation, differentiation and long term survival of granulosa cells, these growth factors are also responsible for mechanistic basis of FSH action [4].

Studies examining the role of the growth factors of bone morphogenetic protein (BMP) family in the reproductive system have led to significant break throughs [5]. The elucidation of aberrant reproductive phenotypes of animals with naturally occurring mutations [6] or targeted deletion [7, 8] of certain genes of BMP family has further highlighted its importance. Three important fecundity genes from BMP family

Copyright: The authors. This article is an open access article licensed under the terms of the Creative Commons Attribution License (http://creativecommons.org/licenses/by/2.0) which permits unrestricted use, distribution and reproduction in any medium, provided the work is properly cited. have been identified in sheep, namely, bone morphogenetic protein receptor type IB (BMPR1B) or activinlike kinase 6 (ALK-6) or FecB on chromosome 6 [9], growth differentiation factor 9 (GDF9) or FecG on chromosome 5 [10] and bone morphogenetic protein 15 (BMP15) or FecX on chromosome X [10]. Naturally occurring mutations in BMP15 [11], GDF9 [12], BMPR1B [13] dramatically influencing the number of ova ovulated in sheep, provides definitive evidences that the ovarian BMPs play a central role in the mechanisms governing ovulation quota and litter size. These studies have further led to the concept that normal ovulation quota requires the regulated expression of BMPs. A common point mutation in BMPR1B gene has been identified in different breeds of sheep (eg. Booroola, Garole, $\mathrm{Hu}, \mathrm{Han}$, and Javanese) [14]. An increased ovulation rate/ litter size is observed in ewes that were heterozygous for the mutation [15]. Ovulation rates were highest in the ewes that were heterozygous mutants in GDF9 and BMP15; whereas, the homozygote mutant showed a primary ovarian failure resulting in a complete sterility in sheep [16, 17]. In case of BMPR1B, super-fertility in heterozygotes is further augmented in homozygotes mutants [18]. While the mechanism of increased ovulation is likely to be similar in naturally occurring mutant of either BMP15 or GDF9 but ewes with simultaneous mutation in both the genes demonstrated higher ovulation rates [10]. The mice lacking BMP15, GDF9 or BMPR1B showed a marked reduction in fertility or complete infertility. The BMP15 knock-out mice exhibited a reduced fertility due to the defect in ovulation and embryo development [8]. However, GDF9 and BMPR1B knock-out mice were infertile due to a block in folliculogenesis at the primary stage $[19,20]$ and defects in the cumulus expansion and fertilization [21], respectively. 


\section{Studies in the farm animals}

Candidate genes expression in the ovary: BMP15 is expressed specifically in the oocyte from the beginning of formation of one-layer primary follicle and it continues till ovulation [22]. In sheep and cattle [23], oocyte expression of GDF9 mRNA begins at the primordial follicle stage but BMP15 is detected only in oocytes from the primary follicle stage onward in sheep. In goat, BMP15 and GDF9 proteins were found in oocytes of all types of follicles and granulosa cells of primary, secondary and antral but not in primordial follicles. The mRNAs for BMP15, GDF9 and BMPR1B was detected in primordial, primary and secondary follicles as well as in oocytes and granulosa cells of antral follicles [24]. reported both GDF9 and BMP15 were maintained in oocytes and granulosa cells (GCs) of porcine from primordial to mature follicles except that GDF9 was undetectable in GCs of mature follicles [22]. However, BMPR1B was found in oocytes and GCs of all follicles in mouse and porcine. GDF9, BMP15 and their receptors might correlate with primordial follicular recruitment in pig.

a. BMP15: Five separate point mutations in the BMP15 gene have been identified to affecting the ovulation rate [10] in sheep. Animals homozygous for each of these mutations are anovulatory and thus sterile; whereas, heterozygous animals have mean ovulation rates between 0.8 and 2.4 above that of the respective noncarrier flocks [10]. The Inverdale and Hanna mutations in the BMP15 gene have dramatic consequences on follicle development in sheep. BMP15 is exclusively expressed in the oocyte within the ovary, with expression increasing in relation to follicle growth and development [6]. Consistent with responsiveness to BMP ligands throughout folliculogenesis, expression of the type I (BMPR1B) and type II (BMPR11) receptors utilized by BMP15 has been confirmed in granulosa cells from the primordial to primary stages onwards [25, 26]. BMP15 actions are regulated by follistatin, a binding protein that can bind BMP15 and negate its activity [6]. Follistatin is strongly expressed in dominant follicles, with very low or undetectable levels in atretic follicles. As BMP15 inhibits FSH receptor expression, follistatin regulation of BMP15 actions is likely important for maintaining granulosa cell responsiveness to FSH.

b. GDF9: GDF9 has high amino acid homology and a similar oocyte-specific ovarian expression pattern to BMP15 [27]. In sheep, it has been observed that a potent action of GDF9 on suppressing both basal and FSH-stimulated progesterone production by ovine granulosa cells from small antral follicles with proliferation being unaffected $[7,15]$. In some Cambridge ewes, a single point mutation has been identified in GDF9 [10]. Each of the above point mutations results in an increased ovulation rate in heterozygous carriers; whereas, primary ovarian failure is observed in the homozygous mutants. The
GDF9 mutation (Belclare; FecGH) corresponds to a non-conservative amino acid substitution at position 77 of the mature protein region. The ovarian phenotype in animals homozygous for this mutation is different than that for the BMP15 mutations in that ovarian follicles continue to develop to the antral (i.e. type 5) stages although most, if not all, are abnormal with respect to oocyte morphology and the arrangement and appearance of the granulosa and cumulus cell-types. In vitro studies using recombinant GDF9 protein have clarified the biological roles and importance of GDF9 actions in follicle growth and development at all stages of folliculogenesis. There is compelling evidence in several mammalian species that GDF9 is essential for early stages of follicle development. GDF9 null mice [19] and ewes either homozygous for naturally occurring mutations in the GDF9 gene [10] or immunized against GDF9 [28] exhibit a block in follicle growth at the primary stage.

C. BMPR1B: Booroola was the first major gene that has been reported to increase ovulation rate [29]. The $\mathrm{FecB}^{\mathrm{B}}$ allele corresponds to a single mutation in the coding sequence of the BMPR1B. BMPR1B is precociously expressed, as early as 25 days postcoïtum (dpc) before the gonadal sex differentiation. BMPR1B expression significantly increases at $56 \mathrm{dpc}$ at the time of germinal cell meiosis. The BMP receptor, BMPR1B is expressed by granulosa cells and oocytes from the primary to the late antral follicle stages and to a lesser extent, by the theca layer of ovine and bovine antral follicles [25,30]. BMPR1B together with BMPRII mRNA have been identified in ovine oocytes of type 1 follicles and expression levels for both remain high throughout the follicular types 1-4 and early type 5 stages of growth [18]. Thereafter, the levels of BMPR1B but not BMPRII mRNA in oocytes decline in large antral follicles. BMPR1B has been described as a potent receptor for various BMP factors [31] including BMP15, BMP2, 4, 6 and BMP7. In FecB animals, a single $A$ to $G$ substitution at nucleotide position 830 results in an arginine replacing a glutamine amino acid in a highly conserved region of this receptor [32]. The dominant phenotype is precocious ovarian follicular development and exceptional prolificacy [33].

\section{Biological functions of candidate genes in regulating follicular development}

Neutralization of either GDF9 or BMP15, alone or together, resulted in alterations of ovarian follicular development in vivo indicating that both GDF9 and BMP15 are likely regulators of ovarian follicular development in cattle [34]. GDF9 and BMP15 alone and in combination suppressed FSH-stimulated progesterone production and stimulated cell proliferation. Both GDF9 and BMP15 have speciesdependent effects. In ovine granulosa cells, ovine BMP15 given together with mouse GDF9 or ovine GDF9 was more potent in stimulating ovine granulosa cells mitosis compared with each growth factor 
independently, while in bovine granulosa cells there is little or no co-operative action between ovine BMP15 and GDF9 in terms of mitotic activity [35]. The species of origin of GDF9 also affected the progesterone response as well as inhibin production by ovine granulosa cells. In terms of fertility, the outcome varied, with some cattle immunized to BMP15 peptide alone becoming anovulatory; whereas, others immunized with BMP15 or BMP15 with GDF9 peptides had increased ovulation rates [34]. Both murine and ovine GDF9+BMP15-stimulated thymidine incorporation in rat granulosa cells was dependent on the SMAD2/3 signaling pathway but not the SMAD1/5/8 pathway [36]. Porcine GDF9 gene was highly expressed in immature oocytes and declined slowly during the oocyte maturation process. But BMP15 mRNA and protein were expressed at low levels in immature oocytes and increased to the highest level at $18 \mathrm{~h}$ of in vitro maturation (IVM), which coincides with the time of cumulus cell expansion [37]. However, the transcription of BMP6, BMP15, GDF9 and BMPR11 were downregulated, while BMP4, BMPR1A and BMPR1B remained unchanged during IVM in pig oocytes. mRNAs of BMPR1A, BMPR1B and BMPR11 were constantly expressed in cumulus cells in the process. However, BMP15 was absent in cumulus cells [38]. The results of the in vitro study in goat indicated $200 \mathrm{ng} / \mathrm{mL}$ GDF9 maintains the survival of preantral follicles and promotes activation of primordial follicles [39]. Lower developmental competence in calf oocytes is associated with immature expression of BMP15/GDF9 in an intrafollicular environment [40]. In chicken, BMP15 and GDF9 expression is maintained during hierarchical follicular maturation in the germinal disc region and then progressively declined after ovulation [41]. Higher ovulation rate in BB sheep (homozygous for a mutation in the bone morphogenetic protein receptor type 1B (BMPR1B) is due, at least in part, to lower oocyte-derived BMP15 mRNA levels together with the earlier onset of LH-responsiveness in GC [42].

\section{Mutations and litter size}

The same FecB mutation (Q249R) occurred in the BMPR1B gene in Small Tailed Han ewes as found in Booroola Merino ewes. An equivalant $\mathrm{Fec}^{\mathrm{G}}$ mutation (Q239Ter) of the BMP15 gene was found in Small Tailed Han ewes as in Belclare and Cambridge ewes. The Small Tailed Han ewes carrying mutations in both BMPR1B and BMP15 genes had greater litter size than those with either mutation alone [43]. The differences in expression levels of BMP15 and BMPR1B may play a role in the increase in ovulation rate observed in Woodlands ewes with FecX2 ${ }^{\mathrm{w}}$ mutation [44]. The inhibitory effect of BMPs and GDF9 on FSH secretion was significantly greater in pituitary cells harvested from Booroola homozygous carrier of BMPR1B mutation when compared with non-carrier animals [45]. $\mathrm{FecX}^{\mathrm{G}}$ and $\mathrm{FecB}$ mutations were not present in
Iranian Baluchi sheep breed. But preliminary polymorphism analysis performed on $\mathrm{FecG}^{\mathrm{I}}$ mutation in GDF9 locus suggested a major gene inheritance of prolificacy in this breed [46]. There was no evidence of mutation in $\mathrm{FecX}^{\mathrm{B}}$ and $\mathrm{Fec} \mathrm{X}^{\mathrm{G}}$ in Iranian goats, all of which were monomorph for exon 2 BMP15 gene [47].

In Yunling black goats, the mRNA expression levels of FSHB, FSHR, and BMP15 positively correlated with litter size, but those of BMPR1B and ESR2 correlated negatively [48]. Polymorphisms of GDF9, BMP15 and BMPR1B genes were not detected in Chinese goats [49]. A point mutation is associated with increased fecundity in heterozygous and infertility in homozygote Thoka ewes [50]. Among the three fecundity genes studied, only the BMPR1B gene was polymorphic in Black Bengal goat [51]. However, another study demonstrated thatthe FecB locus of the BMPR1B gene and G1 locus of GDF9 gene were polymorphic in Garole sheep [52]. Bonpala sheep is the first sheep breed in which concurrent polymorphism at three important loci (FecB, G1, and G4) of two different fecundity genes (BMPR1B and GDF9) has been found [53]. There was a correlation of mutations in BMP15 and GDF9 genes with the control on fecundity of White goat and supported that they were the pivotal factors in female fertility of White goat in Guizhou province [54]. Wang et al (55) reported four mutations in the BB genotype of BMP15 gene of Funiu white goat but there was no mutation in the Taihang black goat. So it is concluded that the BMP15 gene may be a major gene which affects the prolificacy in Funiu white goats [55]. In fat-tailed sheep breed of Iran, mutations in BMP15 and GDF9 genes were associated with increased litter size [56]. However, a study reported polymorphic GDF9 in Sangsari sheep of Iran [57]. But they didn't find any polymorphism in BMP15 loci [57]. BMP15 gene expression and structural difference in the GDF9 and BMPR1B may be associated with the reproductive difference between Lezhi black and Tibetan goats [58]. The analysis of polymorphism for GDF9 $\left(\mathrm{FecG}^{\mathrm{H}}\right)$ loci in Shal sheep indicates that the genetic factor responsible for twinning or multiple lambing rates is not related to reported mutated alleles at the GDF9 major gene in this breed [59]. A4-bp deletion was identified in the coding region of the BMP15 gene in Chinese cows [60]. Recent finding is that the Lleyn breed was the most likely source of the $\mathrm{FecX}^{\mathrm{G}}$ and $\mathrm{FecG}^{\mathrm{H}}$ mutations in Belclare and Cambridge sheep and that the $\mathrm{FecX}^{\mathrm{B}}$ mutation came from the high fertility line [61].

\section{Future prospects and recommendations}

Taken together, these studies shows that BMPs plays an important role in female fertility. The clear association between mutations and deletions in the BMP15 and GDF9 genes and altered reproductive function together with characterization of the biological functions of these genes in follicular cells has established the importance of BMP15 and GDF9 in 
normal female fertility. The advances in the research on the BMP system will help in applications in the animal sector and can be summarized as:

1. Genetic screening of BMP15 and BMPR1B gene mutations in the sheep has already materialize as a method to optimize profitability of sheep farmers (e.g. Marker assisted introgression (MAI) of $\mathrm{Fec}^{\mathrm{B}}$ gene in sheep).

2. The use of the mutant sheep as a model to find genetic markers of prolificacy in genes of the BMP system.

3.The development of some strategies that affect the function of BMPs help in direct manipulation of litter size of domestic species.

4. Researchers have demonstrated either increase or decrease ovulation rate in sheep depending upon the immunization conditions (e.g., anti BMP15/GDF9).

5. Understanding of BMPs in reproduction assists in the treatment of infertility/sterility in animals.

Researchers reported that a correlation between mutations in the GDF9 and BMP15 and diseases such as premature ovarian failure (POF) and polycystic ovary syndrome (POS) [62, 63]. The detection of GDF9 and BMP15 mRNA in normal human oocytes indicates that these factors may play a fundamental role in folliculogenesis and fertility in women [64]. However, there is no report of role of BMPs in the treatment of infertility in farm animals. Studies defining the precise involvement of these factors in ovarian physiology/physiopathology are needed for the advancement of basic science and for the potential application of the knowledge obtained to sterility problem in large animals.

At present, BMP gene clone, construction single chain antibody as well as the clinical practice of BMP genotherapy could prompt broad prospects for BMP application. The multiple high dose injections of BMP15 or GDF9 peptides in sheep and cattle showed production of anovulatory phenotype of homozygous mutants [28,34]. These studies help in the adoption of this technique to use as a permanent, low cost, nonsurgical and safe contraceptive option for women or domesticated mammalian species. However, before treatment with these proteins, translational studies evaluating the effects of treatment doses and timing, as well as the effectiveness of exogenously administering mature protein are warranted.

\section{Conclusion}

The regulated expression of members of BMP family in the ovary is necessary for normal folliculogenesis. The BMP15, GDF9, and BMPR1B are obligatory for folliculogenesis through their ability to stimulate granulose cells proliferation and modulate FSH dependent cytodifferentiation. Naturally occurring mutations and knock-out and knock-down studies in these genes dramatically influencing the ovulation rate in animals, provides definitive evidences that the ovarian BMPs play a central role in the mechanisms governing ovulation quota and litter size.

\section{References}

1. Hunter, M.G., Robinson ,R.S., Mann, G.E. and Webb, R. (2004) Endocrine and paracrine control of follicular development and ovulation rate in farm species. Anim. Reprod. Sci. 82-83: 461-477.

2. Palma, G.A., Arga naraz, M.E, Barrera, A.D., Rodler, D., Mutto A.A. and Sinowatz, F. (2012) Biology and Biotechnology of Follicle Development. The Scientific World Journal. 14. doi:10.1100/2012/938138.

3. Erickson, G.F. and Shimasaki, S. (2003) The spatiotemporal expression pattern of the bone morphogenetic protein family in rat ovary cell types during the estrous cycle. Reprod. Biol. Endocrinol. 1:9.

4. Webb, R. and Campbell, B.K. (2007) Development of the dominant follicle: mechanisms of selection and maintenance of oocyte quality. Soc. Reprod. Fertil. Suppl. 64:141-163.

5. Campbell, B.K., Souza, C.J., Skinner, A.J., Webb, R. and Baird, D.T. (2006) Enhanced response of granulosa and theca cells from sheep carriers of the FecB mutation in vitro to gonadotropins and bone morphogenic protein-2, -4, and 6. Endocrinology. 147:1608-1620.

6. Otsuka, F., McTavish, K.J. and Shimasaki, S. (2011) Integral role of GDF-9 and BMP-15 in ovarian function. Mol. Reprod. Dev.78:9-21.

7. Shi, F.T., Cheung. A.P., Huang, H.F. and Leung, P.C. (2009) Effects of endogenous growth differentiation factor 9 on activin A-induced inhibin B production in human granulosalutein cells. J. Clin. Endocrinol. Metab. 94(12):5108-5116.

8. Yan, C., Wang, P., DeMayo, J., DeMayo, F.J., Elvin, J.A., Carino, C., Prasad, S.V., Skinner, S.S., Dunbar, B.S., Dube, J.L., Celeste, A.J. and Matzuk, M.M. (2001) Synergistic roles of bone morphogenetic protein 15 and growth differentiation factor 9 in ovarian function. Mol. Endocrinol. 15: 854-866.

9. Souza, C.J., MacDougall, C., Campbell, B.K., McNeilly, A.S. and Baird, D.T. (2001) The Booroola (FecB) phenotype is associated with a mutation in the bone morphogenetic receptor type 1 B (BMPR1B) gene. J. Endocrinol. 169:R1R6.

10. Hanrahan, J.P., Gregan, S.M., Mulsant, P., Mullen, M., Davis, G.H., Powell, R. and Galloway, S.M. (2004) Mutations in the genes for oocyte-derived growth factors GDF9 and BMPI5 are associated with both increased ovulation rate and sterility in Cambridge and Belclare sheep (Ovis aries). Biol. Reprod. 70: 900-909.

11. Demars, J., Fabre, S., Sarry, J., Rossetti, R., Gilbert, H., Persani, L., Tosser-Klopp, G., Mulsant, P., Nowak, Z., Drobik, W., Martyniuk, E. and Bodin, L . (2013) GenomeWide Association Studies Identify Two Novel BMP15 Mutations Responsible for an Atypical Hyperprolificacy Phenotype in Sheep. 9:4.

12. Våge, D. I., Husdal, M., Kent, M. P., Klemetsdal, G. and Boman, I. A. (2013) A missense mutation in growth differentiation factor 9 (GDF9) is strongly associated with litter size in sheep. BMC Genet. 14 (1): 1.

13. Reader, K. L., Haydon, L.J., Littlejohn, R.P., Juengel J.L. and McNatty, K.P. (2012) Booroola BMPR1B mutation alters early follicular development and oocyte ultrastructure in sheep. Reprod. Fert. Develop. 24, 353-361.

14. Davis, G.H., Balakrishnan, L., Ross, I.K., Wilson, T., Galloway, S.M., Lumsden, B.M., Hanrahan, J.P., Mullen, M., Mao, X.Z., Wang, G.L., Zhao, Z.S., Zeng, Y.Q., Robinson, J.J., Mavrogenis, A.P., Papachristoforou, C., Peter, C., Baumung, R., Cardyn, P., Boujenane, I., Cockett, N.E., Eythorsdottir, E., Arranz, J.J. and Notter, D. R. (2006) Investigation of the Booroola (FecB) and Inverdale (FecXI) mutations in 21 prolific breeds and strains of sheep sampled in 13 countries. Anim. Reprod. Sci. 92:87-96.

15. Fabre, S., Pierre, A., Mulsant, P., Bodin, L., Pasquale, E.D., 
Persani, L., Monget, P. and Monniaux, D. (2006) Regulation of ovulation rate in mammals: contribution of sheep genetic models. Reprod. Biol. Endocrine. 4:20:1-12.

16. Bodin, L., Di Pasquale, E., Fabre, S., Bontoux, M., Monget, P., Persani, L. and Mulsant, P. (2007) A novel mutation in the bone morphogenetic protein 15 gene causing defective protein secretion is associated with both increased ovulation rate and sterility in Lacaune sheep. Endocrinology. 148(1): 393-400.

17. Monteagudo, L.V., Ponz, R., Teresa, T.M., Lavina, A. and Sierra, I. (2009) A 17 bp deletion in the Bone Morphogenetic Protein 15 (BMP15) gene is associated to increased prolificacy in the Rasa Aragonesa sheep breed. Anim. Reprod. Sci. 110:139-146.

18. Wilson, T., Wu, X.Y., Juengel, J.L., Ross, I.K., Lumsden, J.M., Lord, E.A., Dodds, K.G., Walling, G.A., McEwan, J.C., O'Connell, A.R., McNatty, K.P. and Montgomery, G.W. (2001) Highly prolific Booroola sheep have a mutation in the intracellular kinase domain of bone morphogenetic protein IB receptor (ALK-6) that is expressed in both oocytes and granulosa cells. Biol. Reprod. 64:1225-1235.

19. Dong, J., Albertini, O.F., Nishimori, K., Kumar, T.R., Lu, N. and Matzuk, M. (1996) Growth differentiation factor-9 is required during early ovarian folrliculogenesis. Nature., 383: 531-535.

20. Elvin, J.A., Clark, A.T., Wang, P., Wolfman, N.M. and Matzuk, M.M. (1999) Paracrine actions of growth differentiation factor-9 in the mammalian ovary. Mol. Endocrinol. 13: 1035-1048.

21. Yi, S.E., Lapolt, P.S., Yoon, B.S., Chen, Y.Y., Lu, J.K. and Lyons, K.M. (2001) The typeI BMP receptor BMPR1B is essential for female reproductive function. Proc Natl Acad Sci USA. 98: 7994-7999.

22. Sun, R.Z., Lei, L., Cheng, L., Jin, Z.F., Zu, S.J., Shan, Z.Y., Wang, Z.D., Zhang, J.X. and Liu, Z.H. (2010) Expression of GDF-9, BMP-15 and their receptors in mammalian ovary follicles. J. Mol. Histol. 41:325-332.

23. Bodensteiner, K.J., Clay, C.M., Moeller, C.L. and Sawyer, H.R. (1999) Molecular cloning of the ovine growth/ differentiation factor-9 gene and expression of growth/ differentiation factor-9 in ovine and bovine ovaries. Biol. Reprod. 60: 381-386.

24. Silva, J.R.V., Van den hurk, R., Van tol, H.T.A., Roelen, B.A.J. and Figueiredo, J.R. (2004) Expression of Growth Differentiation Factor 9(GDF9), Bone Morphogenetic Protein 15 (BMP15) and BMP Receptors in the Ovaries of Goats. Mol. Reprod. Dev. 70:11-19.

25. Edson M.A., Nalam, R.L., Clementi, C., Franco, H.L., DeMayo, F.J., Lyons, K.M. Pangas, S.A. and Matzuk, M.M. (2010) Granulosa Cell-Expressed BMPR1A and BMPR1B Have Unique Functions in Regulating Fertility but Act Redundantly to Suppress Ovarian Tumor Development. Mol Endocrinol. 24(6):1251-1266.

26. McNatty, K.P., Galloway, S.M., Wilson, T., Smith, P., Hudson, N.L., O'Connell, A., Bibby, A.H., Heath, D.A., Davis, G,H., Hanhrahan, J.P. and Juengel, J.L. (2005a) Physiological effects of major genes affecting ovulation rate in sheep. Genet. Sel. Evol. 37 (1): 25-38.

27. Dube, J.L., Wang, P., Elvin, J., Lyons, K.M., Celeste, A.J. and Matzuk, M.M. (1998) The bone morphogenetic protein 15 gene is X-linked and expressed in oocytes. Mol. Endocrinol. 12:1809-1817.

28. Juengel, J.L., Hudsorl, N.L., Heath, D.A., Smith, P., Reader, K.L., Lawrence, S.B., O'Connell, A.R, Laitinen, M.P., Cranfield, M., Groome, N.P., Ritvos, O. and McNatty, K.P. (2002) Growth differentiation factor-9 and bone morphogenetic protein 15 are essential for ovarian follicular development in sheep. Biol. Reprod. 67: 1777-1785.

29. Bodin, L., Lecerf, F., Pisselet, C., SanCristobal, M., Bib, B. and Mulsant, P. (2003) How many mutations are associated with increased ovulation rate and litter size and progeny of Lacaune meat sheep? in Proc. Workshop On Major Genes and QTL in Sheep and goat. Toulouse, France, 8-11, December 2003.

30. Glister, C., Satchell, L. and Knight, P.G. (2010) Changes in expression of bonemorphogenetic proteins (BMPs), their receptors and inhibin co-receptor betaglycan during bovine antral follicle development: inhibin can antagonize the suppressive effect of BMPs on thecal androgen production. eproduction. 140699-712.

31. Ten Dijke, P., Korchynskyi, O., Valdimarsdottir, G. and Goumans, M.J. (2003) Controlling cell fate by bone morphogenetic protein receptors. Mol. Cell. Endocrinol., 211:105-113.

32. Hua, G. and Yang, L. (2009) A review of research progress of FecB gene in Chinese breeds of sheep. Anim. Reprod. Sci. 116:1-9.

33. Davis, G.H. (2005) Major genes affecting ovulation rate in sheep. Genet Sel Evol. 37(1):S11-S23.

34. Juengel, J.L., Hudson, N.L., Berg, M., Hamel, K., Smith, P., Lawrence, S.B., Whiting, L. and McNatty, K.P. (2009) Effects of active immunization against growth differentiation factor 9 and/or bone morphogenetic protein 15 on ovarian function in cattle. Reproduction. 138(1):107-114.

35. McNatty, K.P., Juengel, J.L., Reader, K.L., Lun, S., Myllymaa, S., Lawrence, S.B., Western, A., Meerasahib, M.F., Mottershead, D.G., Groome, N.P., Ritvos, O. and Laitinen, M.P. (2005b) Bone morphogenetic protein 15 and growth differentiation factor 9 co-operate to regulate granulosa cell function in ruminants. Reproduction, 129(4): 481-487.

36. Reader, K L., Heath, D.A, Lun, S., McIntosh, C.J., Western, A.H, Littlejohn, R.P., McNatty, K.P., Juengel, J L. (2011) Signalling pathways involved in the cooperative effects of ovine and murine GDF9CBMP15-stimulated thymidine uptake by rat granulosa cells. Reproduction. 142:123-131.

37. Li, H.K., Kuo, T.Y., Yang, H.S., Chen, L.R., Li, S.S.L. and Humang, H.W. (2008) Differential gene expression of bone morphogenetic protein 15 and growth differentiation factor 9 during in vitro maturation of porcine oocytes and early embryos. Anim. Reprod. Sci., 103312-322.

38. Zhu, G., Guo, B., Pan, D., Mu, Y. and Feng, S. (2008) Expression of bone morphogenetic proteins and receptors in porcine cumulus-oocyte complexes during in vitro maturation. Anim. Reprod. Sci. 104:275-283.

39. Martins, F. S., Celestino, J.J.H., Saraiva, M.V.A., Matos, M.H.T, Bruno, J.B., Rocha-Junior, M.C., Lima-Verde, I.B., Lucci, C.M., Báo, S.N. and Figueiredo, J.R. (2008) Growth and differentiation factor-9 stimulates activation of goat primordial follicles in vitro and their progression to secondary follicles. Reprod. Fertil. Dev. 20: 916-924.

40. Hosoe, M., Kaneyama, K., Ushizawa, K., Hayashi, K. and Takahashi, T. (2011) Quantitative analysis of bone morphogenetic protein 15 (BMP15) and growth differentiation factor 9 (GDF9) gene expression in calf and adult bovine ovaries. Reprod. Biol. Endocrinol., 9:33.

41. Elis, S., Dupont, J., Couty, I., Persani, L., Govoroun, M., Blesbois, E., Batellier, F and Monget, P. (2007) Expression and biological effects of bone morphogenetic protein-15 in the hen ovary. J. Endocrinol. 194: 485-497.

42. Crawford, J. L., Heath, D.A., Reader, K.L., Quirke, L. D., Hudson, N.L. and Juengel, J.L. and McNatty, K.P. (2011) Oocytes in sheep homozygous for a mutation in bone morphogenetic protein receptor $1 \mathrm{~B}$ express lower mRNA levels of bone morphogenetic protein 15 but not growth differentiation factor 9. Reproduction. 142: 53-61.

43. Chu, M. X., Liu, Z. H., Jiao, C. L., He, Y. Q., Fang, L., Ye, S. C., Chen, G. H. and Wang, J. Y. (2007) Mutations in BMPRIB and BMP-15 genes are associated with litter size in Small Tailed Han sheep (Ovis aries). J. Anim. Sci. 85:598-603.

44. Feary, E.S., Juengel, J.L., Smith, P., French, M.C., O'Connell, A.R., Lawrence, S.B., Galloway, S.M., Davis, G.H and McNatty, K.P. (2007) Patterns of expression of messenger RNAs encoding GDF9, BMP15, TGFBR1, 
BMPR1B, and BMPR2 during follicular development and characterization of ovarian follicular populations in ewes carrying the Woodlands FecX2W mutation. Biol. Reprod. 77 (6): 990-998.

45. Young, J.M., Juengel, J.L., Dodds, K.G., Laird, M., Dearden, P.K., McNeilly, A.S., McNatty, K.P. and Wilson T. (2008) The activin receptor-like kinase 6 Booroola mutation enhances suppressive effects of bone morphogenetic protein 2 (BMP2), BMP4, BMP6 and growth and differentiation factor-9 on FSH release from ovine primary pituitary cell cultures. J. Endocrinol. 196: 251-261.

46. Moradband, F., Rahimi, G. and Gholizadeh, M. (2011) Association of Polymorphisms in Fecundity Genes of GDF9, BMP15 and BMP15-1B with Litter Size in Iranian Baluchi Sheep. Asian-Aust. J. Anim. Sci. 9: 1179-1183.

47. Deldar-Tajangookeh, H., Shahneh ,A Z, Zamiri M.J., Daliri M., Kohram H. Nejati-Javaremi A. (2009) Study of BMP-15 gene polymorphism in Iranian goats. Afr. J. Biotechnol. 8:2929-2932.

48. Cui, H.X., Zhao, S.M., Cheng, M.L., Guo, L., Ye, R.Q., Liu, W.Q and Gao, S.Z (2009) Cloning and expression levels of genes relating to the ovulation rate of the Yunling black goat. Biol. Reprod. 80:219-226.

49. Yuanqing, He, Ma, X., Liu, X., Zhang, C. and, Li, J. (2010) Candidate Genes Polymorphism and Its Association to Prolificacy in Chinese Goats. J Agric Sci. 2:1.

50. Nicol, L., Bishop, S.C., Pong-Wong, R., Bendixen, C., Holm Lars-Erik, Rhind, S.M., McNeilly, A.S. (2009) Homozygosity for a single base-pair mutation in the oocytespecific GDF9 gene results in sterility in Thoka sheep. Reproduction 138: 921-933.

51. Polley, S., De, S., Batabya, S., Kaushik, R., Arora, J.S., Chattopadhyay, S., Pan, S., Brahma, B., Datta, T.K. and Goswami, S.L. (2009). Polymorphism of fecundity genes (BMPR1B, BMP15 and GDF9) in the Indian prolific Black Bengal goat. Small. Rumin. Res., 85:122-129.

52. Polley, S., De, S., Brahma, B., Mukherjee, A., P.V Vinesh., Batabyal, S., Arora, J.S., Pan S., Samanta, A.K., Datta, T.K. and Goswami, S.L. (2010) Polymorphism of BMPR1B, BMP15 and GDF9 fecundity genes in prolific Garole sheep. Trop. Anim. Health Prod. 42:985-993.

53. Roy, J., Polley, S., De, S., Mukherjee, A., Batabyal, S., Pan, S. Brahma, B., Datta, T.K. and Goswami, S. L. (2011) Polymorphism of fecundity genes (FecB, FecX, and $\mathrm{FecG}$ ) in the Indian Bonpala sheep. Anim Biotechnol., 22:151-62.

54. Xue-qin R., Jian-bin L., Zhi-yong D.U., Cheng QING and
Jia-fu WANG. (2009) Diversity of BMP15 and GDF9 Genes in White Goat of Guizhou Province and Evolution of the Encoded Proteins. Zool. Res. 30(6):593-602.

55. Wang, Y., Yuanxiao, Li., Nana, Z., zhanbin, W. and Junyan, B. (2011) Polymorphism of exon 2 of BMP15 gene and its relationship with litter size of two Chinese goats. Asian Austral. J. Anim. Sci., 24:7.

56. Javanmard, A., Azadzadeh, N. and Esmailizadeh, A.K. (2011) Mutations in bone morphogenetic protein 15 and growth differentiation factor 9 genes are associated with increased litter size in fat-tailed sheep breeds. Vet. Res. Commun. 35:157-167.

57. Kasiriyan, M.M., Hafezian, S.H. and Hassani, N. (2011) Genetic polymorphism BMP15 and GDF9 genes in Sangsari sheep of Iran. Int. Genet. Mol. Biol. 3(1):31-34.

58. Yang, C., Zi, X., Wang, Y., Yang, D., Ma, L., Lu, J., Niu, H. and Xiao, X. (2012) Cloning and mRNA expression levels of GDF9, BMP15, and BMPR1B genes in prolific and nonprolific goat breeds. Mol Reprod Dev. 79(1):2.

59. Ghaffari, M., Nejati-Javaremi, A. and Rahimi-Mianji, G. (2009) Lack of polymorphism in the oocyte derived growth factor (GDF9) gene in the Shal breed of sheep. S. Afr.J. Anim. Sci.39:4.

60. Zhang, L.P., Gan, Q.F., Zhang, X.H., Li, H.D., Hou, G.Y., Li, J.Y., Gao, X., Ren, H.Y., Chen, J.B., Xu, S.Z. (2009) Detecting a deletion in the coding region of the bovine bone morphogenetic protein 15 gene (BMP15). J Appl Genet. 50(2):145-8.

61. Mullen, M.P., Hanrahan, J.P., Howard, D.J. and Powell, R. (2013) Investigation of Prolific Sheep from UK and Ireland for Evidence on Origin of the Mutations in BMP15 $\left(\mathrm{FecX}^{\mathrm{G}}\right.$, $\left.\mathrm{FecX}{ }^{\mathrm{B}}\right)$ and GDF9 $\left(\mathrm{FecG}^{\mathrm{H}}\right)$ in Belclare and Cambridge Sheep. PLOS ONE. 8:1.

62. Takebayashi, K., Takakura, K., Wang, H., Kimura, F., Kasahara, K. and Noda, Y. (2000) Mutation analysis of the growth differentiation factor 9 and $9 \mathrm{~B}$ genes in patients with premature ovarian failure and polycystic ovary syndrome. Fertil. Steril., 74:976-979.

63. Kovanci, E., Rohozinski, J., Simpson, J.L., Heard, M.J., Bishop, C.E. and Carson, S.A. (2007) Growth differentiating factor-9 mutations may be associated with premature ovarian failure. Fertil. Steril., 87:143-146.

64. Filho, F.L.T., Baracat, E.C.and Lee, T.H. (2002) Aberrant expression of growth differentiation factor9 in oocytes of women with polycystic ovary syndrome. J. Clin. Endocrinol. Metab., 87:1337-1344.

$* * * * * * * *$ 